\title{
ESTIMATION OF PROTEIN DIGESTIBILITY IN BRAN FROM DIFFERENT RICE VARIETIES
}

\author{
Danica Andreevska ${ }^{1}$, Dobre Andov ${ }^{1}$, Natasha Gjorgovska ${ }^{2 *}$, Vesna Levkov ${ }^{2}$, \\ Mirjana Menkovska ${ }^{2}$, Svetlana Grigorova ${ }^{3}$, Trajche Dimitrovski ${ }^{4}$ \\ ${ }^{I}$ Field Crops Department, Institute of Agriculture, "Ss. Cyril and Methodius" University in Skopje, \\ Blvd. Aleksandar Makedonski bb, 1000 Skopje, Republic of Macedonia \\ ${ }^{2}$ Department of Nutrition and Foodstuffs Processing, Institute of Animal Science, \\ "Ss. Cyril and Methodius" University in Skopje, Blvd. Ilinden 92a, Skopje, Republic of Macedonia \\ ${ }^{3}$ Nutrition and Feed Technologies Department, Institute of Animal Sciences, Kostinbrod, Bulgaria \\ ${ }^{4}$ Institute of Agriculture, "Ss. Cyril and Methodius" University in Skopje, \\ Blvd. Aleksandar Makedonski bb, 1000 Skopje, Republic of Macedonia \\ *natashagjorgovska@gmail.com
}

\begin{abstract}
A b s t r a c t: Rice is an important cereal crop in the Republic of Macedonia. The process of the post-production of paddy rice results in certain categories of products: brown rice (or cargo), white rice, broken rice, rice hull and rice bran as by-products, which have a wide variety of applications. The focus of our study was to estimate the protein digestibility in rice bran of 8 rice varieties (Prima riska - as standard, San Andrea, Onice, Gloria, Roma, Gala, Halilbey and Gönen). The protein digestibility was determined using in vitro method with pepsin dissolved in $\mathrm{HCl}$. There was a statistically significant difference between the rice varieties in the digestibility of protein and in total fat. The protein digestibility of rice bran ranged from $81.79 \%$ in the Turkish variety Gönen to $88.58 \%$ in the Italian variety Gloria. These results suggest that rice bran is a good source of protein with good biological value and digestibility
\end{abstract}

Key words: rice bran; protein; digestibility

\section{ОЦЕНА НА СВАРЛИВОСТА НА ПРОТЕИНИТЕ ОД ОРИЗОВИ ТРИЦИ ОД РАЗЛИЧНИ СОРТИ ОРИЗ}

\begin{abstract}
А п с т р а к т: Оризот е важна житна култура во Република Македонија. Процесот на постпродукција на ориз резултира со одредени категории производи: кафеав ориз (или карго), бел ориз, кршен ориз, оризова арпа и оризови трици како нус-производи, кои имаат широк спектар на користење. Целта на нашата студија беше да се оцени сварливоста на протеините кај оризовите трици од 8 сорти ориз (Prima riska - како стандард, San Andrea, Onice, Gloria, Roma, Gala, Halilbey и Gönen. Сварливоста на протеините беше определена со употреба на методот in vitro со пепсин растворен во $\mathrm{HCl}$. Имаше статистички значајна разлика помеѓу сортите на ориз во поглед на сварливоста на протеините и во вкупните масти. Сварливоста на протеините на оризовите трици се движи од $81,79 \%$ во турската сорта Gönen до 88,58\% во италијанската сорта Gloria. Овие резултати укажуваат на тоа дека оризовите трици се добар извор на протеини со добра биолошка вредност и сварливост.
\end{abstract}

Клучни зборови: оризови трици; протеини; сварливост

\section{INTRODUCTION}

Rice is an important cereal crop in the Republic of Macedonia. The process of the post-production of paddy rice results in certain categories of products: brown rice (or cargo), white rice, broken rice, rice hull and rice bran as by-products, which have a wide variety of applications (Andreevska $e t$ al. 2017). Rice bran is a by-product of rice milling industry and constitutes around $10 \%$ of the total weight of rough rice (Hu et al., 1996). It is mainly composed of aleurone, pericarp, subaleurone layer 
and germ. Rice bran is a rich source of vitamins, minerals, essential fatty acids, dietary fiber and other sterols (Gul et al., 2015). According to Bocevska (2006), the rice bran is a good source of nutritive, stable and healthy oil. Rice bran is rich in B-vitamins and tocopherols and its nutrient density and profiles of amino-acids and fatty acids, includeing $74 \%$ of unsaturated fatty acids, are superior to those of cereal grains. Both rice bran protein and fat are of relatively high biological value (Khan, 2004). Digestibility of protein is one of the most important data for estimating the protein quality (Han et al., 2015). The focus of this study was to estimate the protein digestibility in rice bran using in vitro method with pepsin dissolved in $\mathrm{HCl}$, in order to suggest rice bran as a new protein source in animal nutrition.

\section{MATERIALS AND METHODS}

The chemical analyses and protein digestibility estimation were conducted on rice bran samples from eight varieties of rice (Oryza sativa L.). The list of the tested bran samples is given in the Table 1.

Table 1

List of rice bran samples from different rice varieties

\begin{tabular}{cll}
\hline \hline No. & Variety & Country of origin \\
\hline 1. & Prima riska (st.) & Macedonia \\
2. & San Andrea & Italy \\
3. & Onice & Italy \\
4. & Gloria & Italy \\
5. & Roma & Italy \\
6. & Gala & Turkey \\
7. & Halilbey & Turkey \\
8. & Gönen & Turkey \\
\hline \hline
\end{tabular}

\section{Protein digestibility}

Protein digestibility of rice bran samples was analyzed using pepsin enzyme dissolved in $\mathrm{HCl}$ according to AOAC 971.09 with modifications. The pepsin was dissolved in $0.075 \mathrm{~N} \mathrm{HCl}$, previously warmed to $40-42^{\circ} \mathrm{C}$. To each defatted sample in flask, $150 \mathrm{ml}$ of freshly prepared pepsin solution was added. The sample was incubated at temperature of $42-45^{\circ} \mathrm{C}$ and constantly agitated during 16 hours' incubation. After incubation, the sample was filtered and the residue was transferred in a Kjeldahl flask to perform Kjeldhal digestion and extraction.

\section{Chemical analyses of samples}

After milling the rice bran using laboratory mill the samples were stabilized at room temperature. The chemical analyses comprised: moisture content, total protein content, total fat content and ash content. The moisture content was measured applying a standard drying method for the samples in an oven at the temperature of $105 \pm 5^{\circ} \mathrm{C}$, till constant weight. The total protein content was determined according to Kjeldahl method $(\mathrm{N} \times 5.95)$. The total fat content was analyzed by extraction with diethyl ether according to the Soxhlet method. Ash content was determined by burning the samples in oven during 8 hours at the temperature of $600^{\circ} \mathrm{C}$.

\section{RESULTS AND DISCUSSION}

In Table 2 are presented the minimal, maximal and average values of the percentage of husk and bran of different rice varieties analyzed in this study.

The bran percentage ranged from $6.85 \%$ in Gala variety to $9.90 \%$ in Onice. Rice variety Roma had the highest fraction of husks (24.15\%), while Gala the lowest (18.45\%). The percentages of bran and husk in the standard variety Prima riska were $9.55 \%$ and $21.10 \%$, respectively.

Table 2

Amount of husk and bran yield

of analyzed rice varieties (\%)

\begin{tabular}{llccc|ccc}
\hline \hline & \multicolumn{4}{c|}{ Husk } & \multicolumn{3}{c|}{ Bran } \\
\cline { 2 - 6 } No. Variety & $\min$ & $\max$ & average & $\min$ & $\max$ & average \\
\hline 1. Prima riska(st.) & 20.1 & 22.1 & 21.10 & 8.9 & 10.2 & 9.55 \\
2. San Andrea & 19.7 & 22.0 & 20.85 & 6.1 & 9.0 & 7.55 \\
3. Onice & 18.0 & 23.6 & 20.80 & 6.4 & 13.4 & 9.90 \\
4. Gloria & 20.4 & 22.4 & 21.40 & 8.7 & 9.2 & 8.95 \\
5. Roma & 23.1 & 25.2 & 24.15 & 7.3 & 9.8 & 8.55 \\
6. Gala & 18.0 & 18.9 & 18.45 & 5.9 & 7.8 & 6.85 \\
7. Halilbey & 19.7 & 23.6 & 21.65 & 6.0 & 8.6 & 7.30 \\
8. Gönen & 18.7 & 19.8 & 19.25 & 6.7 & 7.7 & 7.20 \\
\hline \hline
\end{tabular}


Table 3 presents the approximate chemical composition in rice bran. The average moisture content in the bran of the investigated rice varieties ranged from $11.87 \pm 0.24 \%$ in the variety Gala to $13.57 \pm 0.12 \%$ in Halilbey. San Andrea, Gloria and Halilbey had significantly higher moisture content $(\mathrm{P} \leq 0.01)$ compared to the standard Prima riska.)

The highest lipid content (Table 3 ) in the rice bran was found in the variety Gönen (14.29 \pm $0.32 \%)$, and the lowest in the variety San Andrea $(10.12 \pm 0.08 \%$,$) . Onice, Roma, Gala and Gönen$ had significantly higher $(\mathrm{p} \leq 0.01)$, while San Andrea significantly lower lipid content $(\mathrm{p} \leq 0.01)$ compared to the standard variety Prima riska. The average ash content in the rice bran ranged from $6.76 \pm 0.12 \%$ for the variety San Andrea to $10.46 \pm$ $0.10 \%$ for the variety Gönen. In the varieties San
Andrea, Gloria, Roma and Halilbey the ash content was significantly lower $(\mathrm{p} \leq 0.01)$ compared to the standard variety Prima riska, while the varieties Gönen ( $\mathrm{p} \leq 0.01)$ and Gala $(\mathrm{p} \leq 0.05)$ contained significantly higher ash content than the standard. The approximate chemical composition of rice bran is similar with the results reported by Singh et al. (2013), Satter et al. (2014) and Andreevska et al. (2017).

The carbohydrates content ranged from 58.69 $\pm 0.65 \%$ in variety San Andrea (the highest average) to $50.16 \pm 0.79 \%$ in the variety Gönen (the lowest).

In comparison to the standard Prima riska, the content of carbohydrates was significantly higher in San Andrea $(\mathrm{p} \leq 0.01)$, Gloria $(\mathrm{p} \leq 0.01)$ and Halilbey $(\mathrm{p} \leq 0.05)$, while significantly lower in Onice and Gönen $(\mathrm{p} \leq 0.01))$.

Table 3

Approximate chemical composition of different varieties' rice bran (\%)

\begin{tabular}{|c|c|c|c|c|c|}
\hline No. & Variety & Moisture & Lipid & Ash & Carbohydrates \\
\hline 1. & Prima riska (st.) & $12.00 \pm 0.26$ & $11.15 \pm 0.11$ & $9.96 \pm 0.08$ & $54.01 \pm 0.29$ \\
\hline 2. & San Andrea & $13.16 \pm 0.38^{* *}$ & $10.12 \pm 0.08^{* *}$ & $6.76 \pm 0.12^{* *}$ & $58.69 \pm 0.65^{* *}$ \\
\hline 3. & Onice & $12.24 \pm 0.18$ & $13.73 \pm 0.10^{* *}$ & $9.97 \pm 0.21$ & $51.24 \pm 0.11^{* *}$ \\
\hline 4. & Gloria & $12.80 \pm 0.17^{* *}$ & $11.22 \pm 0.19$ & $9.00 \pm 0.13^{* *}$ & $55.27 \pm 0.33^{* *}$ \\
\hline 5. & Roma & $12.15 \pm 0.40$ & $11.69 \pm 0.23^{* *}$ & $9.46 \pm 0.07^{* *}$ & $53.89 \pm 0.13$ \\
\hline 6. & Gala & $11.87 \pm 0.24$ & $11.85 \pm 0.25^{* *}$ & $10.41 \pm 0.17^{*}$ & $54.67 \pm 0.24$ \\
\hline 7. & Halilbey & $13.57 \pm 0.12^{* *}$ & $10.83 \pm 0.30$ & $8.94 \pm 0.40^{* *}$ & $55.00 \pm 0.47^{*}$ \\
\hline \multirow[t]{4}{*}{8.} & Gönen & $12.14 \pm 0.52$ & $14.29 \pm 0.32^{* *}$ & $10.46 \pm 0.10^{* *}$ & $50.16 \pm 0.79^{* *}$ \\
\hline & Average & 12.49 & 11.86 & 9.37 & 54.11 \\
\hline & LSD 0.05 & 0.56 & 0.39 & 0.34 & 0.73 \\
\hline & LSD 0.01 & 0.78 & 0.54 & 0.47 & 1.02 \\
\hline
\end{tabular}

Values are means \pm S.D., $* \mathrm{p} \leq 0.05 ; * * \mathrm{p} \leq 0.01$; compared to the standard variety Prima riska

The rice bran as shown in Table 4 contains high crude protein amount, ranging from $11.19 \pm$ $0.06 \%$ in Gala variety to $12.95 \pm 0.30 \%$ in Gönen variety, which makes them a moderately good source of protein. In the varieties San Andrea, Gloria, Gala and Halilbey the crude protein content in the bran was significantly lower than in the standard $(\mathrm{p} \leq 0.01)$.

The presented results are similar to the ones by Satter et al. (2014), who reported protein content in bran from 12.26 to $14.01 \%$. Pepsin digestibility was the highest for Gloria variety $(88.58 \pm 0.71 \%)$, followed by San Andrea $(88.46 \pm 1.55 \%)$, and the lowest in Gönen $(81.79 \pm 2.19 \%)$. In the varieties San Andrea and Gloria digestibility was significant higher than the standard $(\mathrm{p} \leq 0.01)$. The results obtained in this study show lower values for protein digestibility compare to the results of Han et al. (2015). 
Table 4

Content of protein and digestibility of protein in different rice varieties (\%).

\begin{tabular}{llc}
\hline \hline No. $\quad$ Variety & \multicolumn{1}{c}{ Protein } & $\begin{array}{c}\text { Digestibility } \\
\text { of protein }\end{array}$ \\
\hline 1. Prima riska (st.) & $12.88 \pm 0.03$ & $83.28 \pm 2.26$ \\
2. San Andrea & $11.27 \pm 0.18^{* *}$ & $88.46 \pm 1.55^{* *}$ \\
3. Onice & $12.82 \pm 0.19$ & $85.16 \pm 1.26$ \\
4. Gloria & $11.70 \pm 0.43^{* *}$ & $88.58 \pm 0.71^{* *}$ \\
5. Roma & $12.80 \pm 0.37$ & $82.68 \pm 3.06$ \\
6. Gala & $11.19 \pm 0.06^{* *}$ & $86.24 \pm 2.81$ \\
7. Halilbey & $11.66 \pm 0.41^{* *}$ & $84.69 \pm 1.18$ \\
8. Gönen & $12.95 \pm 0.30$ & $81.79 \pm 2.19$ \\
\hline Average & 12.16 & 85.11 \\
LSD 0.05 & 0.47 & 3.66 \\
LSD 0.01 & 0.66 & 5.07 \\
\hline \hline
\end{tabular}

$* \mathrm{p} \leq 0.05$

** $\mathrm{p} \leq 0.01$; compared to the standard variety Prima riska,

Values are means \pm S.D.

\section{CONCLUSION}

The rice bran showed good nutritional quality in all (the) 8 rice varieties. The moisture, lipid, protein, carbohydrate and ash contents showed highly significant differences among the rice varieties. The protein digestibility of rice bran ranged from $81.79 \%$ in the Turkish variety Gönen to $88.58 \%$ in the Italian variety Gloria. These results suggest that rice bran is a good source of protein with good biological value and digestibility.

\section{REFERENCES}

[1] Andreevska, D., Andov, D., Menkovska, M., Gjorgovska, N., Levkov, V., Dimitrovski, T. (2017): Physicochemical properties of some domestic and introduced rice varieties. IRomanian Agricultural Research, vol. 34, pp. 9-14.

[2] AOAC International (1999): Official Methods of Analysis of AOAC International. $19^{\text {th }}$ ed., $5^{\text {th }}$ rev., Method 971.09. Gaithersburg, MD, USA.

[3] Bocevska, M. (2006): Rice bran and hull in oil industry. Uljarstvo, vol. 37, no. 1-2, pp. 15-27.

[4] Gul, K., Yousuf, B., Singh, A. K., Singh, P., Wani, A. A. (2015): Rice bran: Nutritional values and its emerging potential for development of functional food - A review. Bioactive Carbohydrate and Dietary Fibre, vol. 6, no. 1, pp. 24-30.

[5] Han, S. W., Chee, K. M., Cho, S. J. (2015): Nutritional quality of rice bran protein in comparison to animal and vegetable protein. Food Chemistry, vol. 172, pp. 766-769.

[6] Hu, W., Wells, J. H., Shin, T. S., Godber, J. S. (1996) Comparison of isopropanol and hexane for extraction of vitamin $\mathrm{E}$ and oryzanols from stabilized rice bran. Journal of the American Oil Chemists' Society, vol. 73, no. 12, pp. 1653-1656.

[7] Khan, A. D. (2004): Making rice bran a cereals alternative. Feed International, June: 18-19.

[8] Satter, A. M., Arra, H., Jabin, S. A., Abedin, N., Azad, A. K., Hossain, A., Ara, U. (2014): Nutritional composition and stabilization of local variety rice bran BRRI-28. International Journal of Science and Technology, vol. 3, no. 5, pp. 306-313.

[9] Singh, P., Yadav, N., Mishra, P. K., Sheikh, S. (2013): Utilization of rice bran for the development of value added Indian Sweet. International Journal of Agricultural and Food Science, vol. 3, no. 2, pp. 76-79. 